\title{
KeMAMPUAN PEDAgogiK MATEMATIKA SD PADA MAHASISWA PGSD FIP UNIMA
}

\author{
Deysti Trifena Tarusu \\ Program Studi PGSD, FIP, Universitas Negeri Manado \\ Jl Tondano, Koya, Tondano Selatan, Manado, Sulawesi Utara, 95618, Indonesia \\ deystitarusu@unima.ac.id
}

\begin{abstract}
Abstrak
Mempunyai gambaran/deskripsi mengenai kemampuan pedagogik matematika mahasiswa PGSD merupakan suatu hal yang sangat penting bagi pimpinan dan dosen PGSD, khususnya bagi dosen yang mengajarkan mata kuliah pembelajaran matematika. Penelitin ini bertujuan untuk menindaklanjuti perkuliahan matematika di PGSD agar dapat menghasilkan calon guru SD yang profesional. Oleh karena itu, penelitian deskriptif analitik yang bersifat eksploratif untuk mengembangkan kemampuan pedagogik matematika mahasiswa calon guru sekolah dasar (SD) penting bagi dosen mata kuliah pembelajaran matematika. Teknik pengumpulan data diperoleh dari observasi presentasi kelompok dan simulasi dari setiap mahasiswa dalam kegiatan perkuliahan Pembelajaran Matematika. Dengan demikian informasi arahan untuk menentukan tindak lanjut pengembangan pedagogik matematika agar mahasiswa memiliki kemampuan untuk membelajarkan siswa mengenai materi-materi matematika yang diperoleh secara akurat. Hasil penelitian menunjukkan bahwa: a. kemampuan mahasiswa PGSD FIP Unima dalam merancang pembelajaran matematika SD sudah baik. b. melaksanakan pembelajaran matematika SD yang mendidik dan dialogis sudah baik. c. pemanfaatan teknologi pembelajaran matematika SD masih perlu ditingkatkan. d. membuat alat evaluasi belajar matematika SD juga masih perlu ditingkatkan. Dari hasil penelitian ini diperoleh bahwa walaupun kemampuan dalam merancang dan melaksanakan pembelajaran sudah baik, namun dalam penggunaan media atau alat peraga pembelajaran yang masih kurang. Selain itu juga alat evaluasi belum mencakup ranah afektif dan psikomotor, serta evaluasi ranah kognitif juga masih kurang baik.

Kata Kunci: Kemampuan Pedagogik, Matematika SD, Mahasiswa PGSD
\end{abstract}

\begin{abstract}
Having description about pedagogic ability of student mathematics of PGSD is a very important thing for PGSD leader and lecturer, especially for lecturer who teach math learning course. This research aims to follow up the math lectures at PGSD in order to produce prospective elementary school teachers who are professional. Therefore, explorative analytic descriptive research to develop pedagogic ability of mathematics of elementary school teacher (SD) is important for lecturer of mathematics learning subject. Technique of collecting data obtained from observation of group presentation and simulation of each student in lecturing activity of Mathematics Learning. Thus the direction information to determine the follow-up development of pedagogic mathematics so that students have the ability to teach students about mathematical materials obtained accurately. The results showed that: a. the ability of PGSD FIP Unima students in designing elementary mathematics learning is good. b. carrying out educational and dialogical mathematics teaching is good. c. the use of mathematics learning technology elementary still need to be improved. $d$. making the evaluation tool of elementary mathematics learning also still need to be improved. From the results of this study obtained that although the ability in designing and implementing learning is good, but in the use of media or teaching aids are still lacking. In addition, evaluation tools have not included affective and psychomotor spheres, and cognitive domain evaluation is also still not good.

Keyword: Pedagogic Capabilities, Elementary Mathematics, PGSD Students
\end{abstract}




\section{Pendahuluan}

Undang-undang RI No.14 tahun 2005 tentang guru dan dosen menyatakan bahwa kompetensi yang harus dimiliki oleh seorang guru adalah kompetensi kepribadian, kompetensi pedagogik, kompetensi profesional dan kompetensi sosial. Keempat kompetensi guru tersebut merupakan suatu perpaduan dari pengetahuan, keterampilan dan sikap yang dapat mewujudkan kecerdasan serta bertanggung jawab dalam melaksanakan apa yang telah menjadi tugasnya. Mahasiswa PGSD FIP Unima dalam hal ini merupakan calon guru SD harus mempersiapkan dirinya untuk menjadi guru SD yang professional, memiliki wawasan yang luas, berintelektual yang tinggi serta memiliki kompetensi dalam mengembangkan pengetahuan dan keterampilannya dalam mengajar. Kemampuan pedagogik dibutuhkan seiring dengan materi pelajaran baik berupa teori, konsep, prosedur, serta fakta yang merupakan dasar dalam pengembangan pemahaman lebih lanjut. Pengalaman kemampuan pedagogik dan materi pelajaran yang dikembangkan pada mahasiswa calon guru di lembaga pendidikan tinggi keguruan (LPTK) secara lebih khusus di Pendidikan Guru Sekolah Dasar (PGSD) yang terdapat dalam perkuliahan kependidikan (pedagogik) dan pembelajaran matematika. Selain pengalaman yang diperoleh dari dosendosen dalam memberikan pembelajaran saat perkuliahan.
Perkuliahan pembelajaran matematika dapat mengembangkan pemahaman matematis seperti kemampuan dasar yang harus dimiliki mahasiswa untuk mencapai kemampuan matematis lainnya hingga dapat memahami materi matematika pada jenjang yang lebih tinggi (Suherman, 2008: 54). Di samping mengembangkan kemampuan dalam memahami materi dan praktik pedagogik matematika, mahasiswa PGSD yang telah mendapatkan perkuliahan pembelajaran matematika dapat menunjukkan hasil pengalaman kuliahnya melalui latihan praktek (simulasi) mengajarkan matematika di SD dan hasil ujian akhir. Hasil yang ditunjukkan merupakan suatu wujud dari pemahaman mahasiswa akan pedagogik pada pembelajaran matematika.

Pembelajaran merupakan pengalaman yang dapat mengubah perilaku seseorang dari tidak tahu menjadi tahu, dari tidak mengerti menjadi mengerti (Hamzah Uno, 2006). Pengalaman belajar itu dapat diperoleh mahasiswa melalui pembelajaran yang telah dipaparkan oleh dosen. (Mellado, 1998) menyatakan bahwa cara para dosen mengajar sangat mempengaruhi mahasiswa untuk dapat mengajar dibanding materi mengenai teknik mengajar yang baik yang dipaparkan oleh dosen dalam perkuliahan perkuliahan. Selain itu juga Salah satu faktor yang mempengaruhi permasalahan dalam pembelajaran adalah terkait pemanfaatan sumber-sumber belajar yang optimal oleh guru (Mangelep, 2017).

Oleh sebab itu perlu untuk diteliti apakah pengalaman dalam mempelajari materi dengan pengalaman yang diperoleh 
melalui teknik mengajar dosen tentang pembelajaran matematika dapat memberikan serta mengembangkan kemampuan mahasiswa PGSD dalam mengajarkan matematika SD? Rumusan masalah dalam penelitian ini secara umum adalah, "Bagaimana kemampuan pedagogik matematika SD pada mahasiswa PGSD FIP Unima ditinjau dari kemampuan mengelola pembelajaran matematika SD?"

Penelitian ini bertujuan untuk mendapatkan fakta mengenai kemampuan pedagogik matematika SD pada mahasiswa PGSD FIP Unima. Penelitian ini dilaksanakan untuk mendapatkan deskripsi mengenai kemampuan mahasiswa, dalam mengelola pembelajaran matematika SD yaitu (1) merancang pembelajaran matematika SD dalam hal ini pembuatan RPP sesuai kurikulum KTSP 2006; (2) melaksanakan pembelajaran matematika SD yang mendidik, bersifat terbuka dan komunikatif; (3) memanfaatkan teknologi pembelajaran dalam mengajakan matematika SD; (4) membuat alat penilaian belajar matematika di tingkat SD.

penelitian ini bermanfaat bagi pimpinan fakultas terlebih pimpinan program studi dan juga para dosen pengajar matematika di Prodi PGSD FIP UNIMA untuk dapat mengetahui kenyataan yang ada mengenai kemampuan pedagogik dan pemahaman mahasiswa mahasiswa PGSD FIP UNIMA mengenai pembelajaran matematika untuk siswa SD, sebagai bahan informasi untuk digunakan sebagai landasan dalam menindak lanjuti kegiatan perkuliahan Pembelajaran Matematika pada mahasiswa PGSD FIP UNIMA yang adalah calon guru SD, memperkaya pengetahuan mahasiswa calon guru SD pada umumnya, dan juga sebagai masukkan bagi peneliti lain yang berminat menindaklanjuti hasil penelitian ini dengan mengambil penelitian yang berbeda.

\section{Metode}

Metode penelitian yang digunakan adalah penelitian kuantitatif deskriptif dan dokumentasi. Metode penelitian kuantitatif deskriptif adalah metode dengan cara mendapatkan data dari objek secara alamiah dan terstruktur, yang dilaksanakan melalui pemberian tugas, tes/ujian akhir dari kegiatan perkuliahan pembelajaran matematika selama satu semester terhadap mahasiswa PGSD. Data yang terkumpul kemudian dianalisis melalui instrumen perencanaan dan pembelajaran serta evaluasi pemeblajaran matematika. Populasi dalam penelitian ini adalah mahasiswa PGSD FIP UNIMA angkatan 2014 tahun akademik 2015/2016. Sampel adalah mahasiswa PGSD FIP UNIMA angkatan 2014 tahun akademik 2015/2016 semester genap kelas $\mathrm{A}$ dan kelas $\mathrm{H}$ yang mengontrak mata kuliah pembelajaran matematika SD.

Data dalam penelitian ini berupa tugas terstruktur dan simulasi pembelajaran matematika SD untuk melihat kemampuan praktek menguasai dan mengajarkan matematika SD, soal tes/ujian akhir semester tentang pendidikan matematika 
yang menunjukn kemampuan mereka dalam memahami matematika SD.

Instrumen penelitian terlebih dahulu dilakukan uji internal melalui validitas isi dan validitas konstruk guna mendapatkan instrumen yang valid dan reliabel.

Teknik analisis data dalam penelitian ini melakukan pemisahan antara hasil pengukuran kemampuan pedagogik dan pembelajaran matematika, untuk ditelaah dengan menggunakan statistik tendensi sentral kemudian dideskripsikan.

\section{Hasil dan Pembahasan}

\section{A. Hasil Penelitian}

Dengan menggunakan acuan kategori klasifikasi sangat tinggi sampai sangat rendah dari Rakhmat dan Solehudin (2006: 65) secara umum kemampuan mahasiswa dalam merancang pembelajaran matematika SD memiliki kemampuan tingkat sangat tinggi dan tinggi, yaitu 50\% mahasiswa yang menunjukkan kemampuan sangat tinggi dan 50\% mahasiswa menunjukkan kemampuan tinggi. Namun secara spesifik ditemukan sebanyak $26,8 \%$ mahasiswa yang berada di batas akhir kategori tinggi.

Pengalaman merancang pembelajaran matematika SD ini difasilitasi oleh Kurikulum KTSP 2006 untuk Mata Pelajaran Matematika maupun Tematis. Sistematika rancangan pembelajaran (RPP) matematika untuk siswa SD yang dibuat oleh mahasiswa PGSD FIP UNIMA, sudah diawali oleh penulisan Identitas, Standar Kompetensi, Kompetensi Dasar, Indikator, Tujuan Pembelajaran, Ringkasan Materi,
Penentuan Pendekatan, Strategi, Metode, Teknik, Langkah-langkah Pembelajaran dan penjabarannya yang terpilah menjadi tiga bagian yaitu; Pendahuluan, Inti, dan Penutup, serta tidak ketinggalan Alokasi Waktu yang digunakan setiap langkah pembelajaran, Sumber serta Media pembelajaran, dan Penilaian.

Seluruh mahasiswa PGSD FIP UNIMA dalam kemampuan menyusun Identitas, Standar Kompetensi, Kompetensi Dasar, Indikator yang lengkap dan benar ada pada kategori kemampuan tinggi. Dalam mengembangkan Indikator menjadi Tujuan Pembelajaran rata-rata menunjukkan kategori sedang. Paparan materi, secara umum/rata-rata mahasiswa menunjukkan kemampuan pada kategori tinggi.

Selanjutnya, mengenai komponen pendekatan, strategi, metode, teknik, ditunjukkan oleh semua mahasiswa yang hanya menuliskan satu dari empat indikator yang tersedia. Mahasiswa hanya menulis indikator metode saja atau model saja. Tidak ada pencantuman yang lengkap mengenai penggunaan pendekatan, strategi, model dan metode pembelajaran yang akan dilakukan dalam pembelajaran nanti. Seluruh mahasiswa dalam menentukan komponen pedagogik ini termasuk kategori tingkat rendah. Sedangkan paparan langkah-langkah kegiatan pembelajaran ditunjukkan mahasiswa PGSD secara umum/rata-rata memiliki kemampuan tinggi, baik dari merancang kegiatan pembelajaran yang dimulai dari pendahuluan, inti, maupun dalam kegiatan penutup. 
Pelaksanaan simulasi pembelajaran sesuai rencana yang dibuat, secara umum dapat ditunjukkan mahasiswa secara baik. Pada saat sesi pendahuluan dilaksanakan oleh 48\% mahasiswa sesuai dengan yang dirancang bahkan cocok untuk siswa SD. Mahasiswa sudah dapat membuat suasana awal belajar yang kondusif. Mereka melaksanakan kegiatan pendahuluan yang sangat baik, kategori penilaian dalam kemampuan pengkondisian, apersepsi, orientasi dan motivasi termasuk sangat tinggi. Sebagian lagi yaitu 52\% mahasiswa memiliki kemampuan melaksanakan pendahuluan pembelajaran yang baik. Bagi mahasiswa yang berada pada kategori baik, perlu mengoptimalkan kegiatan pendahuluan melalui pelaksanaan kegiatan yang tertinggal seperti apersepsi, orientasi, atau motivasi.

Selanjutnya dalam kegiatan inti ditunjukkan mahasiswa secara umum mampu melaksanakan dalam kualitas kategori tinggi. Dalam kegiatan inti, ditemukan hal teknis yang masih perlu ditingkatkan yaitu fleksibel dalam membuat suasana belajar yang cocok untuk siswa SD, yaitu memunculkan suasana ke SDan yang dapat dengan mudah diterima dan disenangi siswa SD tanpa lepas dari konten materi yang perlu dikuasai siswa.

Terakhir pada kegiatan penutup pembelajaran, sebagian besar mahasiswa PGSD FIP UNIMA mampu melaksanakan kegiatan penutup pembelajaran dalam kualitas kategori tinggi. Meskipun demikian, masih perlu mengoptimalkan kegiatan penutup, yaitu dalam penarikan kesimpulan bersama siswa, penegasan yang kuat dari mahasiswa, penyampaian informasi hasil belajar serta tindak lanjut dari hasil belajar yang diraih oleh siswa.

Kemampuan mahasiswa dalam memanfaatkan teknologi pembelajaran matematika diperlihatkan oleh sebanyak $30 \%$ mahasiswa yang memiliki kemampuan menentukan pilihan dan menggunakan teknologi pembelajaran matematika dengan sangat tinggi. Sebanyak 25\% mahasiswa lainnya memiliki kemampuan menentukan pilihan dan penggunaan teknologi pembelajaran matematika yang masuk dalam kategori sedang. Sisanya yaitu 45\% mahasiswa dapat menentukan pilihan dan penggunaan teknologi pembelajaran matematika pada tingkat kualitas yang tinggi.

Kemampuan mahasiswa dalam membuat alat evaluasi belajar matematika diperlihatkan oleh sebanyak 73.2\% mahasiswa, memiliki kemampuan menentukan dan membuat alat evaluasi pada tingkat tinggi. Sebanyak 26,8\% mahasiswa lainnya memiliki kemampuan menentukan dan membuat alat evaluasi belajar matematika dalam kategori sedang.

\section{B. Pembahasan}

Terdapat 26,8\% mahasiswa yang perlu diingatkan dan ditingkatkan wawasan dan keterampilan dalam merancang pembelajaran matematika agar memiliki kemampuan yang lebih baik dari sebelumnya. Hal ini menjadi pekerjaan 
dosen pengajar matematika di PGSD FIP UNIMA dalam menyisipkan hal rancangan pembelajaran matematika serta dosen pembimbing program pengalaman lapangan (PPL).

Kemampuan dalam merancang pembelajaran matematika ini minimal harus dimiliki oleh seluruh mahasiswa PGSD FIP UNIMA dalam kualitas kategori tinggi. Hal ini diperlukan, sebab perencanaan harus dibuat sebaik mungkin, agar realisasinya dalam kegiatan pembelajaran adalah pembelajaran yang baik pula. Perencanaan pembelajaran yang baik dapat memberikan kontribusi yang baik pada proses dan hasil pembelajaran. Dengan demikian rancangan pembelajaran yang menunjukkan kualitas sedang atau cukup bahkan di bawah itu, membuat kurang baik dalam pelaksanaan pembelajarannya nanti.

Temuan dari rencana pelaksanaan pembelajaran yang perlu ditingkatkan adalah pembuatan tujuan pembelajaran. Sebanyak 70\% mahasiswa belum dapat mencantumkan empat indikator tujuan pembelajaran yang harus ada. Terutama selalu bermasalah dalam menentukan indikator afektif yang diharapkan dan indikator kondisi. Kesulitan tersebut dikarenakan mahasiswa belum menguasai kata kerja operasional yang boleh digunakan dalam tujuan pembelajaran, serta yang tepat digunakan untuk ketercapaian belajar matematika. Penentuan kondisi pada tujuan pembelajaran yang masih jauh dari harapan, berlanjut pada penentuan pendekatan, strategi, metode, atau model pembelajaran yang kurang sesuai untuk pembelajaran matematika tersebut.

Pemaparan materi ajar untuk dipelajari siswa disajikan secara baik. Ditemukan $12,5 \%$ mahasiswa yang perlu meningkatkan kemampuan mencantumkan paparan materi yang terstruktur dan sistematis.

Sesuai dengan temuan pada pembuatan tujuan pembelajaran, hal berikutnya yang perlu ditingkatkan adalah pencantuman pendekatan, strategi, metode yang lengkap sesuai dengan keperluan kegiatan pembelajaran yang membuat siswa aktif. Kelemahan/ketidaklengkapan dalam mencantumkan pendekatan, strategi, metode, disebabkan seluruh mahasiswa belum memiliki wawasan tentang pendekatan, strategi, metode dalam kualitas cukup. Dengan demikian, mereka tidak mengetahui pendekatan, strategi, metode apa yang harus dipilih dan cocok digunakan pada pembelajaran matematika.

Namun demikian mahasiswa dapat mensimulasikan pembelajaran sedemikian rupa sehingga cukup menyenangkan dan berusaha mewujudkan pembelajaran yang aktif. Hal ini ditunjukkan mulai dari kegiatan pendahuluan yang bagus. Hanya satu indikator saja yang tertinggal (tidak dilaksanakan) oleh 49\% mahasiswa yaitu apersepsi, orientasi atau motivasi. Sisanya yaitu 51\% mahasiswa melakukannya secara lengkap. 
Dalam kegiatan inti, 75\% mahasiswa sudah berusaha mewujudkan kegiatan belajar yang berpusat pada siswa, dan hasilnya cukup bagus. Dengan demikian lebih bagus pelaksanaan pembelajarannya dibanding deskripsi kegiatan pembelajaran yang ditulis pada rencana pelaksanaan pembelajaran. Masih ada 13\% yang perlu arahan tambahan terkait bagaimana melaksanakan pembelajaran yang membuat siswa aktif dan mengurangi aktifitas guru menyeramahi/memberitahu siswa. Sebanyak $12 \%$ pula mahasiswa sudah sangat bagus dalam melaksanakan pembelajaran sesuai harapan kurikulum.

Pada kegiatan penutup, 70\% mahasiswa sudah berusaha mewujudkan kegiatan penutup dengan baik. Namun masih ada 10,5\% yang perlu arahan tambahan terkait bagaimana melaksanakan penutup pembelajaran yang membuat siswa puas dan ingin belajar kembali. Sebanyak 19,5\% pula mahasiswa sudah sangat bagus dalam melaksanakan penutup pembelajaran sesuai harapan kurikulum.

Hal yang dianggap remeh namun penting yaitu alokasi waktu pembelajaran yang dicantumkan pada rencana pelaksanaan pembelajaran, ini sudah dibuat dan dilaksanakan dengan sangat baik oleh $75.5 \%$ mahasiswa. Namun $12 \%$ mahasiswa masih perlu diingatkan dan diarahkan untuk merancang alokasi waktu kegiatan pembelajaran. Terakhir yang termasuk kegiatan penutup yaitu pemberian evaluasi, ini sudah sangat baik dilaksanakan oleh mahasiswa, meskipun masih terdapat 26.8\% mahasiswa yang perlu perbaikan dalam melaksanakan evaluasi. Perbaikan tersebut berupa peringatan dalam memeriksa dan mengumumken hasil evaluasi pembelajaran, yang harus menjadi pemicu semangat untuk belajar lebih lanjut dan meningkatkan rasa ingin tahu akan hasil yang benar. Selanjutnya akan lebih baik kalau ada reward terhadap hasil belajar yang telah dicapai siswa.

Menggunakan media teknologi dalam pembelajaran berupa power point masih perlu ditingkatkan. Dalam merancang power point sekitar 75\% mahasiswa yang sudah berusaha merancang materi pembelajaran pada power point dengan begitu menarik dengan cara menambahkan animasi-animasi yng memudahkan siswa untuk lebih paham dengan materi yang diajarkan.

Sekitar 73,2\% mahasiswa yang sudah mulai dapat merancang alat evaluasi pembelajaran yang mencakup ranah kognitif, afektif dan psikomotor dalam alat evaluasi yang mereka buat. Sebanyak 26,8\% mahasiswa perlu dilatih lagi untuk dapat merancang alat evaluasi yang benarbenar bisa mencakup kemampuan kognitif, afektif dan psikomotor siswa.

\section{Penutup}

Berdasarkan hasil penelitian yang sduah dikemukakan dapat disimpulkan bahwa kemampuan mahasiswa PGSD FIP UNIMA dalam merancang pembelajaran matematika SD sudah baik. 
Kemampuan mahasiswa melaksanakan pembelajaran matematika SD secara umum sudah baik serta menunjukkan kemampuan berdialog yang mendidik bagi siswa. Namun dalam menggunakan media teknologi masih perlu ditingkatkan dan merancang alat evaluasi juga belum mencapai semua ranah sehinggah perlu dilatih lagi. Masih banyak mahasiswa yang menggunakan alat evaluasi ranah kognitif tanpa menggunakan taksonomi Bloom. Di samping itu masih kurang mahasiswa yang membuat alat evaluasi untuk ranah afektif dan psikomotor.

Berdasarkan kesimpulan maka bebarapa hal yang perlu diperhatikan, disikapi dan diberi tindakan lebih telaten adalah: 1) pengembangan tujuan pembelajaran yang relevan dengan kompetensi dan indikator yang telah ditentukan, 2) menggali pendekatan, strategi, metode, dan teknik untuk dipilih dan dicantumkan dalam RPP, serta dilaksanakan dalam pembelajaran, 3) memberi pengertian lebih jelas tentang apersepsi, orientasi, dan motivasi untuk dijabarkan pada RPP dan dilaksanakan pada kegiatan pendahuluan, 4) menambah wawasan tentang evaluasi dan asesmen.

Tentu akan lebih baik lagi apabila ditunjang oleh pemanfaatan teknologi pembelajaran matematika yang cocok untuk anak SD. Penggunaan teknologi pembelajaran yang tepat guna ini akan membuat kualitas pembelajaran yang lebih baik sehingga pesan mendidik pun menjadi lebih baik. Dengan demikian penentuan pilihan dan penggunaan teknologi yang tepat guna masih perlu bimbingan.

Hasil dan temuan dari penelitian ini merupakan titik tolak bagaimana menyelenggarakan perkuliahan pendidikan matematika bagi mahasiswa PGSD. Sudah semestinya tindakan dari dosen pengajar matematika di PGSD FIP UNIMA dan juga dosen pembimbing program pengalaman lapangan (PPL) dalam mengajar memberikan materi dan cara mengajar yang baik, sebagai bekal dan contoh yang baik bagi mahasiswa. Dengan demikian pernyataan bahwa guru sulit sekali berubah (Davis, 2003) dapat diantisipasi dengan memberikan pengalaman belajar yang konsisten dan kontinu dari dosen secara baik pula.

\section{Daftar Pustaka}

Davis, K. S. (2003). "Change is hard": What science are telling us about reform dan teacher learning of innovative practises. Science and Education, 87(1), 3-30.

Hamzah Uno. (2006). Perencanaan Pembelajaran. Jakarta: Bumi Aksara

Mangelep, N. O. (2017). Pengembangan Website Pembelajaran Matematika Realistik untuk Siswa Sekolah Menengah Pertama. Mosharafa: Jurnal Pendidikan Matematika, 6(3), 431-440.

Mellado, V. (1998). The classroom practise of preservice teacher and their cinception of teaching and learning. Science education, 82, 197-214 
Presiden Republik Indonesia. Undang Undang Republik Indonesia Nomor 14 Tahun 2005 tentang Guru dan Dosen.

Rakhmat, Solehudin. (2006). Pengukuran dan Penilaian Hasil Belajar. Bandung: CV Andira.
Suherman Ar, E. (2003). Strategi Pembelajaran Matematika Kontemporer. Bandung: JICA-UPI.

\section{Riwayat Hidup PenUlis}

\section{Deysti Trifena Tarusu, S.Pd., M.Pd.}

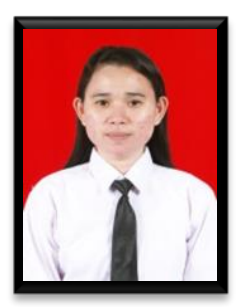

Lahir di Betania pada tanggal 10 April 1988 adalah seorang dosen tetap pada Prodi PGSD FIP UNIMA. Penulis menyelesaikan studi S1 pada Jurusan Pendidikan Matematika Fakultas Matematika dan Ilmu Pengetahuan Alam Universitas Negeri Manado di Tondano, Sulawesi Utara pada tahun 2010, dan menyelesaikan studi S2 pada Program Studi Manajemen Pendidikan, Pascasarjana Universias Negeri Manado di Tomohon, Sulawesi Utara pada tahun 2014. 
This page is intentionally left blank 